\title{
Art Deco in American Song: Holland Robinson's Loose Lyrics of Lovely Ladies and Mac Harshberger's Drawings
}

\author{
Donald Callen Freed ${ }^{*}$
}

If there is an art deco period in American music, its height probably would have been the 1920s. Art deco received much impetus from the French, as did a significant quantity of American music during the period. Into this scene stepped composer Holland Robinson (ca. 1897-1945); this is primarily about one set of Holland Robinson's songs, Loose Lyrics of Lovely Ladies (1928). Robinson also wrote other sets of songs and individual songs, some with his own lyrics and some with texts by others; Appendix 1 provides a complete list of songs by Holland Robinson. Robinson was part of a collaborative artistic circle that included artist Mac Harshberger, and Harshberger's sister Kay. He also received patronage from Edward G. and Gladys Robinson (no relation), among others. The songs, twelve in all, are about historic women and are humorous, witty, clever, and sometimes tongue-in-cheek, stretching the truth about their subjects. They are self-published; the original hardbound edition was limited to 150 copies. Each is two or three pages long, and is from one- to one-and-onehalf minutes in duration. Most are at a moderate tempo and in regular meter, traits of the popular song at this time. Witticism and quoting often appear in Robinson's score, and are described and illustrated in detail, including homage to Liszt, Chopin, Johann Strauss Jr., as well as other folk songs, madrigals, national anthems, and styles. The songs are light, and tonal in scope, and usually have an accompanying figure or two, often established in the introduction. Yet there is spice: "lucrezia borgia" begins with a major seventh/minor seventh alternation, for example. Colorful use of other seventh and ninth chords, used in jazz of the 1920s and 1930s, and liberal use of the tritone in the melody, add to the overall effect. Each song in Loose Lyrics of Lovely Ladies is preceded by a Mac Harshberger drawing/caricature of the personage, in India ink; the drawings are clearly art deco in style. Possible compositional influences on Holland Robinson include the Cocteau songs of Arthur Honegger (Six Poesies de Jean Cocteau, 1920-1923); the previously mentioned "La Diva de 'l 'Empire'" (1919) by Erik Satie, as well as popular songs of French music halls. The light flavor of the songs is also evocative of the music of other members of Les Six besides Honegger, especially Francis Poulenc (i.e., "Violon" or "Hôtel"), as well as popular songs of French music halls, although no influence can be directly documented. If American art deco style in music could be defined on the basis of the songs of Holland Robinson (and the accompanying drawings of Mac Harshberger), it would be light, airy, and clever, full of witticism and double entendre, as one might expect.

\section{Introduction}

If there is an art deco period in music, its height probably would have been in the 1920s. Art deco received much impetus from the French, as did a significant quantity of American music during the period. Art music of this period included Erik Satie, the composers of Les Six such as Francis Poulenc and Arthur Honegger, and the requisite number of Americans studying in Paris with noted teacher Nadia Boulanger, such as Aaron Copland and Roy Harris. Igor Stravinsky was also an influence at this time, as were cabaret songs of the Parisian nightclubs, and by Austro-German composers such as Arnold Schoenberg, all helping to influence this blended style. American song, in particular, had much to

*Professor Emeritus of Voice, Composer-in-Residence, Sul Ross State University, USA. 
owe to the French, particularly the Parisian, influence, and the crossover between classic and popular styles, including jazz, occurred not only in France but also in Great Britain and the United States.

Into this scene stepped composer Holland Robinson (1897-ca. 1945), a devotee of the visual arts as well as a musician, and his friend and artist colleague Mac Harshberger (1900-1975), an artist who loved and felt at home in the relatively new deco style. This article is primarily about one set of Holland Robinson's songs, Loose Lyrics of Lovely Ladies (1928). ${ }^{1}$ Loose Lyrics is the longest and most creative set of songs in Robinson's oeuvre, thus making them a fit introduction to the composer/lyricist. Robinson also wrote other sets of songs and individual songs, some with his own lyrics and some with texts by others; one set of songs, Ballads of a New York Child, was even illustrated by Robinson. (See Appendix 1 for a list of songs by Holland Robinson.) In general, his songs reflect the harmonic usage of Satie, Maurice Ravel, and Claude Debussy, along with rhythms of jazz. ${ }^{2}$

\section{Literature Review}

The literature on the subjects of Robinson and Harshberger is sparse. Most of it is authored by Harshberger's cousin, William Whitney, late of San Francisco, California, USA. The main work is An Elegance of Line: The Graphic Art of Mac Harshberger, published in 1996. The only references to Robinson are in Nancy Lindley's unpublished doctoral dissertation from 1993, Singer Radiana Pazmor and American Music: The Performer as Advocate. Some information about Robinson was gathered from this writer's personal correspondence with William Whitney himself.

\section{An Artistic Circle}

A discussion of Loose Lyrics must also include the previously mentioned Mac Harshberger, who illustrated these and several other sets of Robinson's songs with art deco India ink black-and-white or color drawings. Robinson songs and Robinson/Harshberger collaborations are very difficult to obtain, with only a few copies of some songs held in libraries.

While comparatively little is known about these men, they did live in France, and study, at least peripherally, French art and music in the early 1920s.

1. Holland Robinson, and Mac Harshberger, Loose Lyrics of Lovely Ladies (New York: Holland Robinson, 1928).

2. William Whitney, "Art among Friends," The Sophisticate: Journal of the Art Deco Society of California (San Francisco: Autumn, 1998a), 1-7. 
The Tacoma, Washington natives sailed for Paris in 1921, bankrolled by Harshberger's father. Robinson makes light of this in a short book called Carcassonne and Company: The Diary of an Art Student (1926), ${ }^{3}$ a journal of their artistic and mostly other observations in portions of central and southern France. According to art historian William Whitney (1915-2004), a late cousin of Harshberger who lived in San Francisco, the duo left Paris in the mid 1920s, settling in New York and establishing an art and music studio in the Steinway Building on West 57th Street. Mac Harshberger's sister, Kay, who was just divorced from a noted French gentleman, Jean de Landry, and who wrote lyrics for other Robinson songs, joined them in this artistic enterprise. Kay was also the subject and/or model for Mac's art deco drawings and paintings. ${ }^{4}$ She also introduced them to many persons from the world of arts, letters, and society who also patronized them, such as the actors George Arliss, Sam Jaffe, and Edward G. and Gladys Robinson. The dedicatees of songs also reflected women in society and the arts at the time: Nina (Nina Payne) in "josephine," Kay Harshberger in "cleopatra," Mina (singer Mina Hager) in "pocohantas," and Radiana (singer Radiana Pazmor) in "lucrezia borgia."5

\section{Songs of Loose Lyrics}

The songs, twelve in all, are about historic women and are humorous, witty, light, clever, and sometimes tongue-in-cheek. They are self-published; the original hardbound edition was limited to 150 copies. Each is two or three pages long, and is from one- to one-and-one-half minutes in duration. Most are at moderate tempo and regular meter. Robinson wrote the words as well as the music; his wit shines through in their marriage with each woman's character. The text is in all lower case and sometimes without punctuation, like the poems of e.e. cummings (1894-1962), who also lived in France for a while and was writing at this time. Lyrics are occasionally sprinkled with French text, just as Erik Satie dabbles in English in his mélodie "La Diva de 'l'Empire'" (1919), also a witty song with much double entendre. Satie also used India ink drawings by Charles Martin, which are a precursor to the art deco style, as well as elegant calligraphy, in his Sports et divertissements, a set of twenty piano pieces composed in $1914 .^{6}$

3. Holland Robinson, Carcassonne and Company: The Diary of an Art Student (Binghamton, N.Y.: Vail Ballou Press, 1926).

4. Ibid.

5. Nancy E. Lindley, Singer Radiana Pazmor and American Music: The Performer as Advocate (unpublished doctoral dissertation, University of Maryland, 1993), 127.

6. Erik Satie, and Charles Martin, Sports et divertissements: Twenty Short Pieces for Piano (Paris: Lucien Vogel, 1914). 


\section{Quoting of Composers and Famous Works}

Witticism and quoting often appear in Robinson's score. In "madame sand," there are "apologies to frederic" and "ditto to franz" when passages similar to their works (i.e., a Chopin nocturne and a Liszt character piece) appear in the accompaniment. "La Marseillese," the French national anthem, is quoted and distorted in "josephine." A madrigal or lute song a la Thomas Morley is suggested in "elizabeth" ("hey, nonny, nonny, nonny"). Shifts between major and minor are used to indicate pathos or delight, such as in the ending of "marie antoinette," which also features parallel chromatic triads ("swept our marie antoinette away") and open chords ("calmly went to the block"). A waltz in f minor, with the notation "the very, very blue danube" (Johann Strauss Jr.) highlights Maria Theresa's prayer. The song "helen," about Helen of Troy, a fitting subject for this article, goes back and forth between the chromatic mediants of A major and $\mathrm{C}$ major, starting in A but ending in C. The rolled chords in the piano accompaniment are reminiscent of a Greek lyre (Figures 1-6). 
Figure 1. From "madame sand," passages similar to Chopin and Liszt, m. 17-24 madame sand

Iyric and music by holland robinson
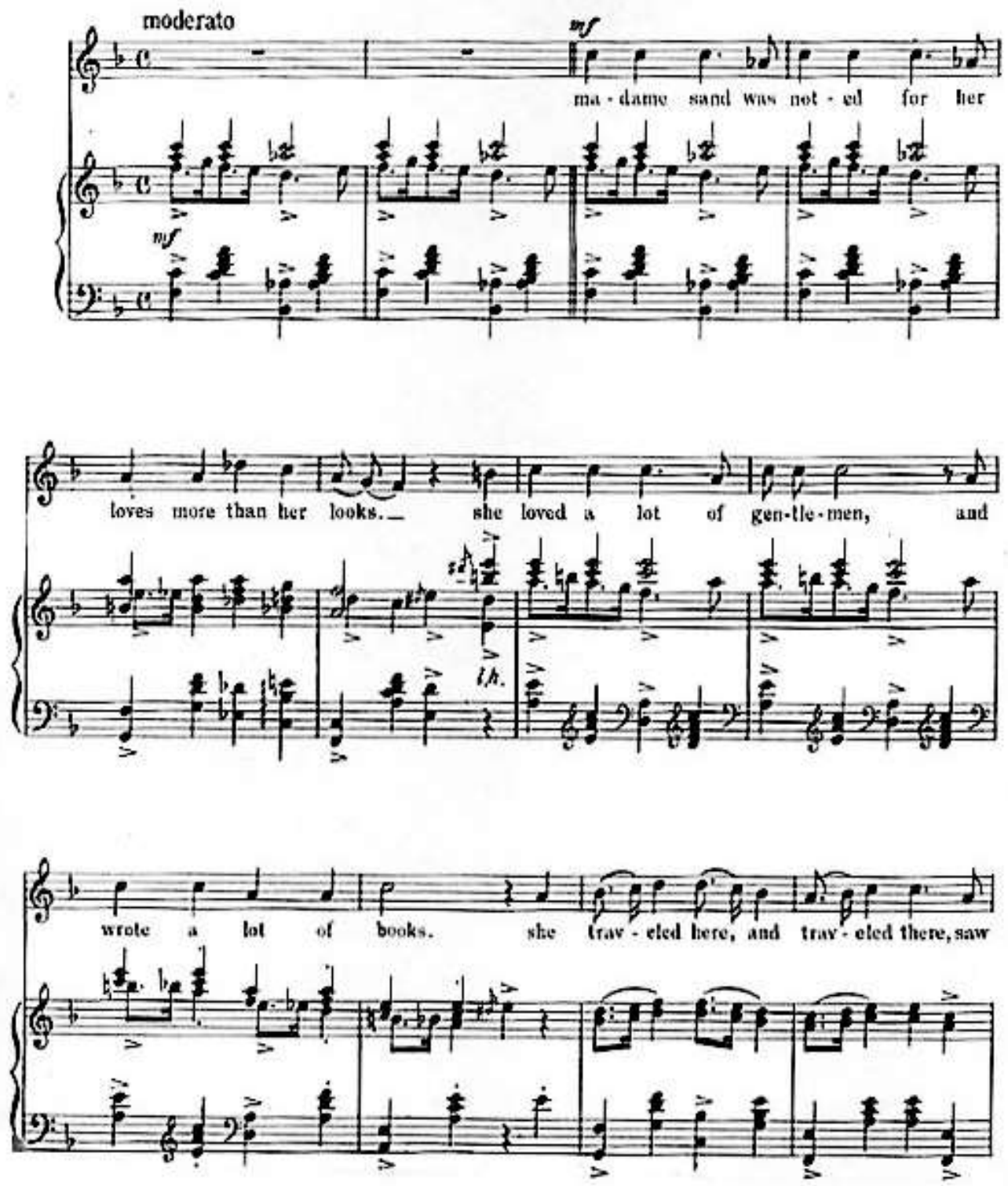

froen "loove lyike of berely todies"

eopyrielt 192A by tolland robiaton 

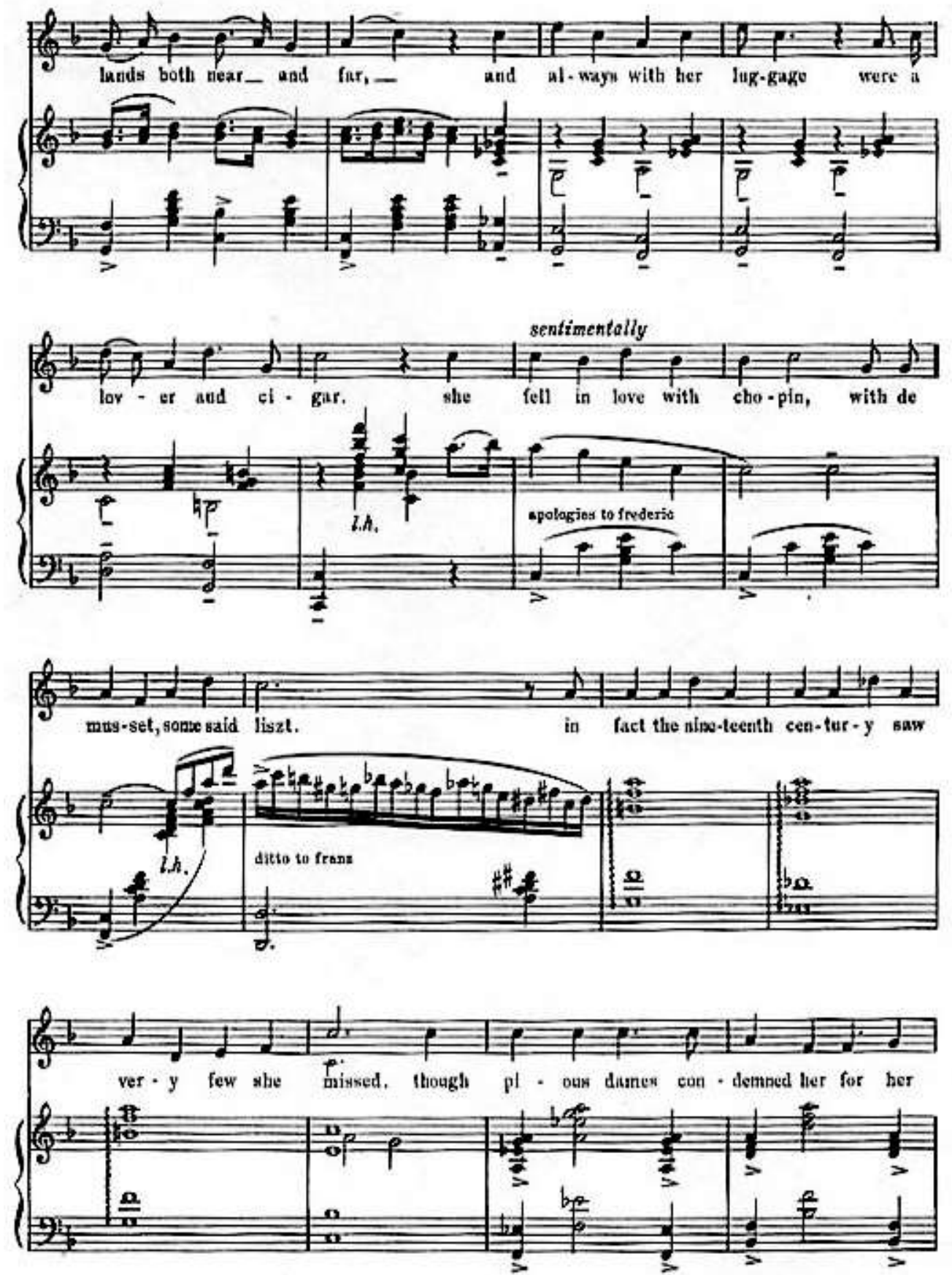

madarro and - 8 

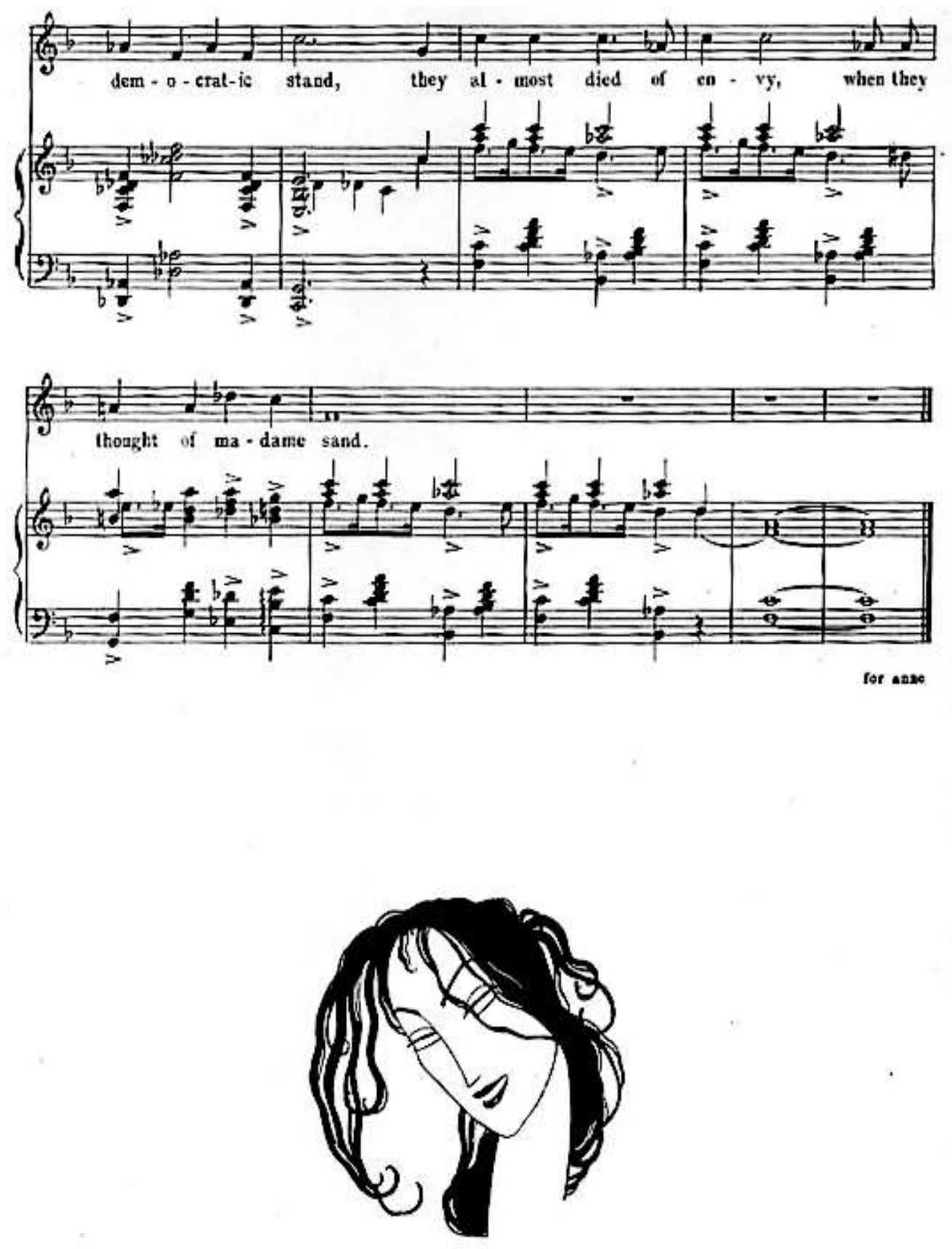
Figure 2. "La Marseillese" in "josephine," m. 11-20

\section{josephine}
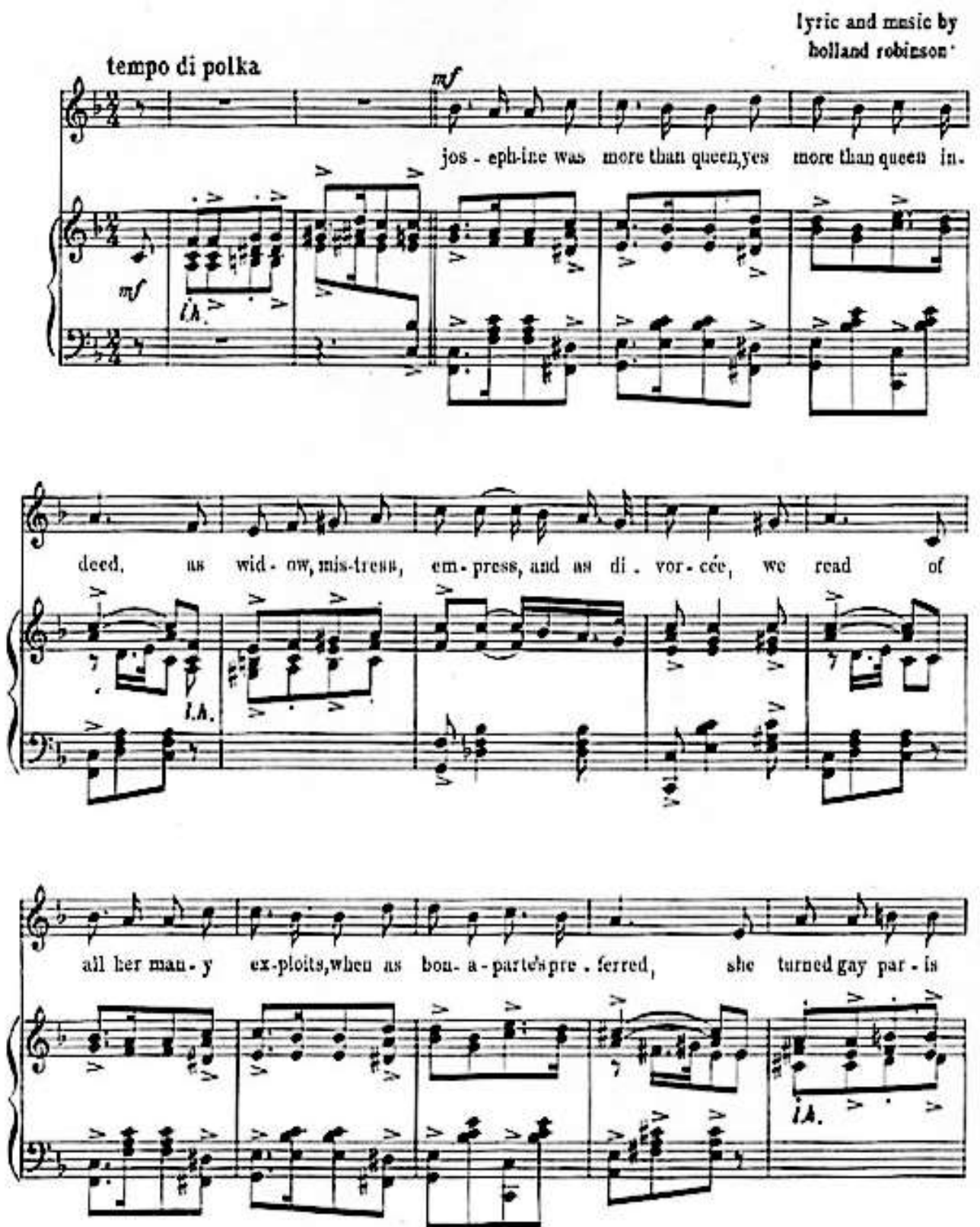

frez"toese lyzles of lavely Indien" 

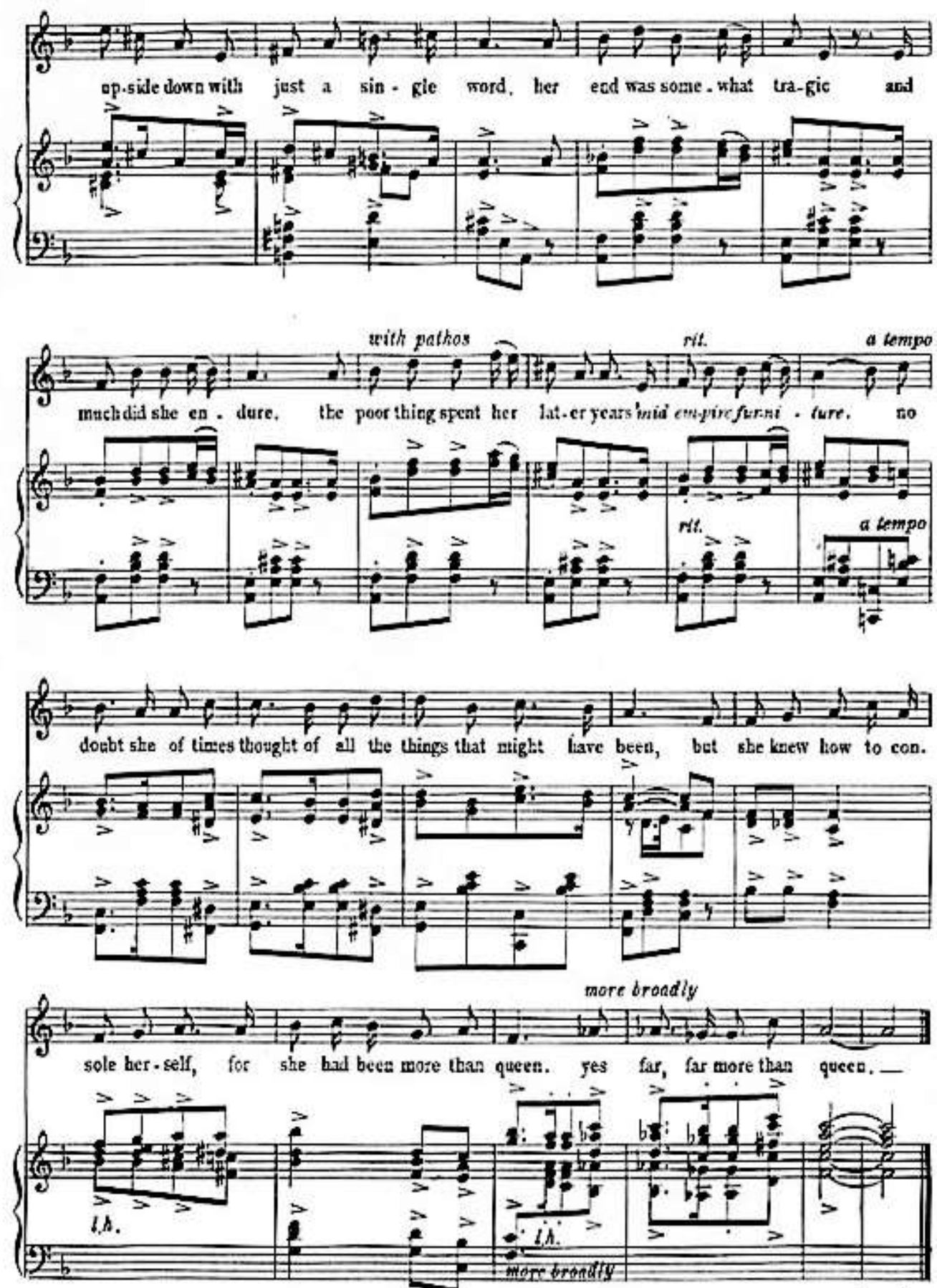

for nlak 
Figure 3. "Elizabeth," recalling a lute song or madrigal

\section{elizabeth}

Irric aed masic by bolland tobiavo
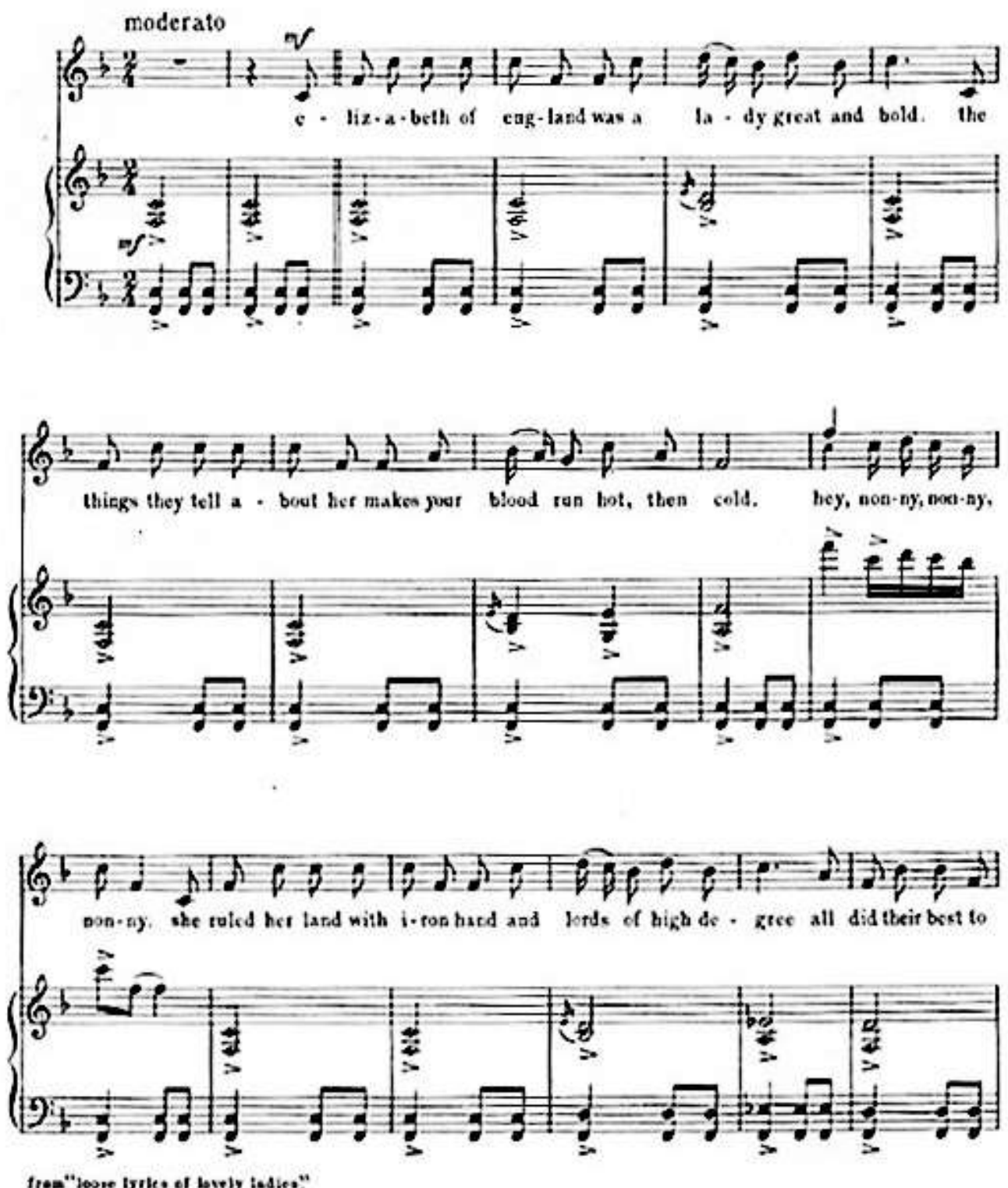

eapriket thes by bollsed callowe 
Figure 4. The ending of "marie antoinette," m. 15-24
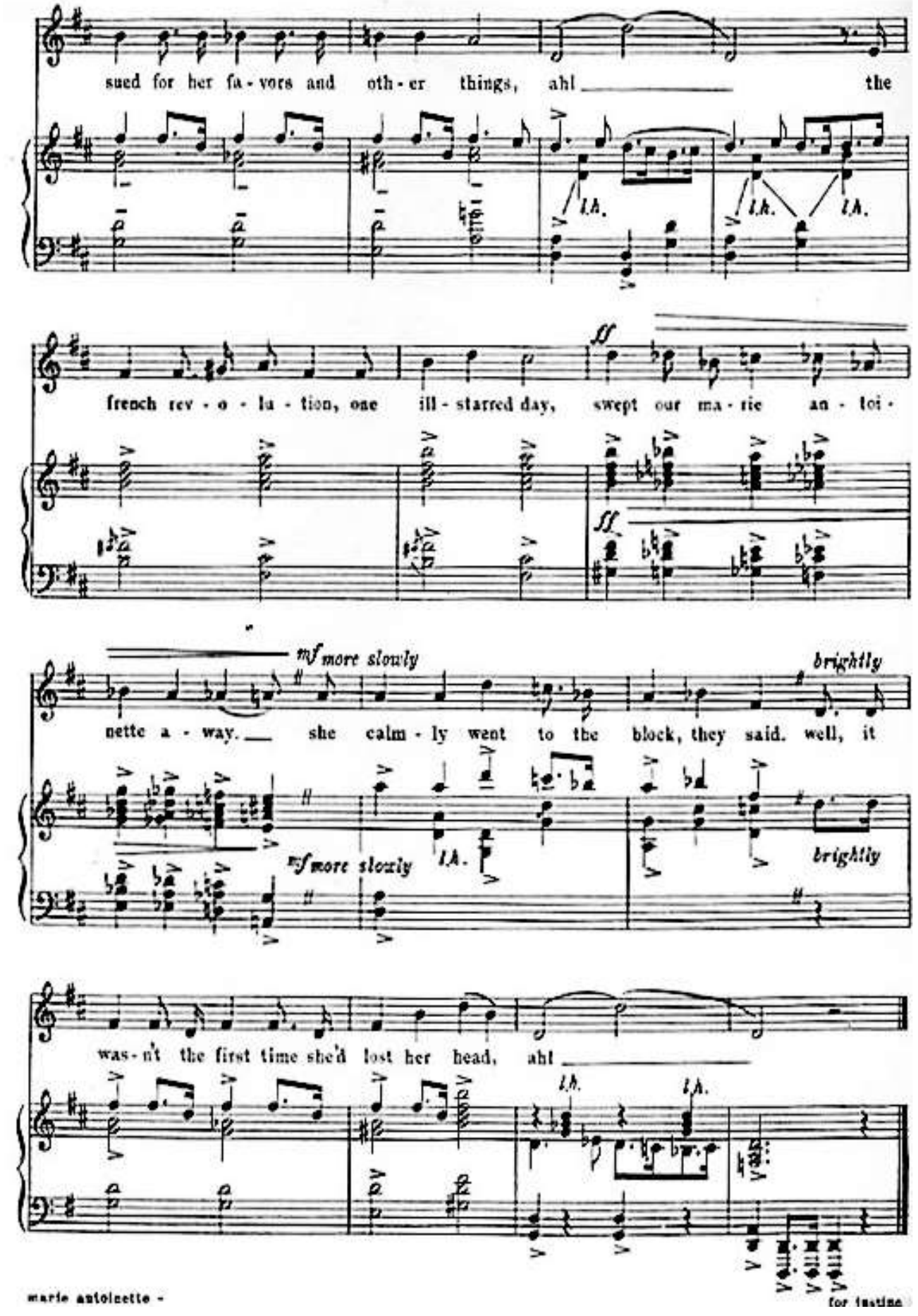
Figure 5. "The very, very blue danube," in "maria theresa," m. 19-28
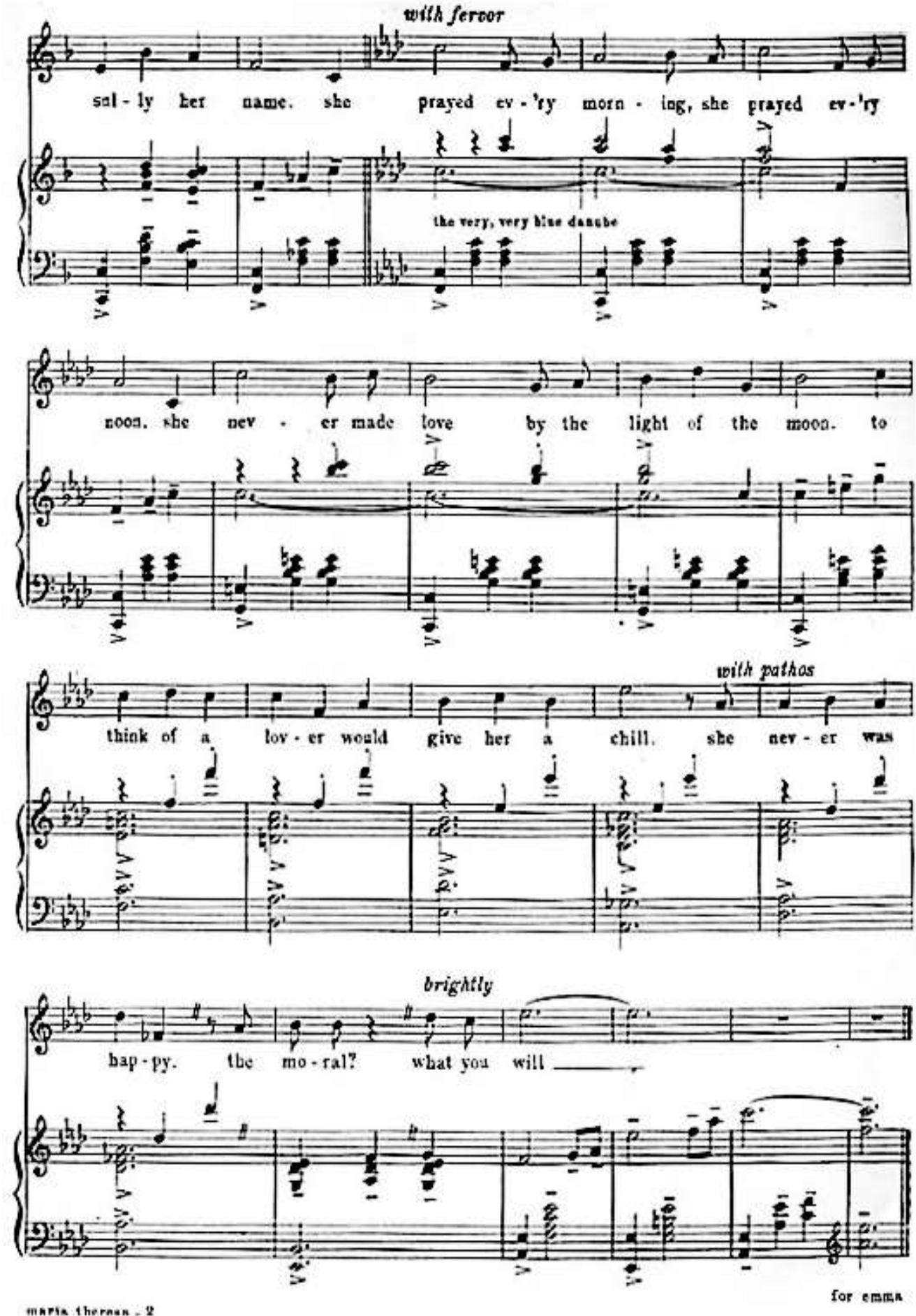
Figure 6. Drawing by Mac Harshberger, and complete music for "helen"

\section{helen of troy}

1yric aed mesic by

colliand robiesos
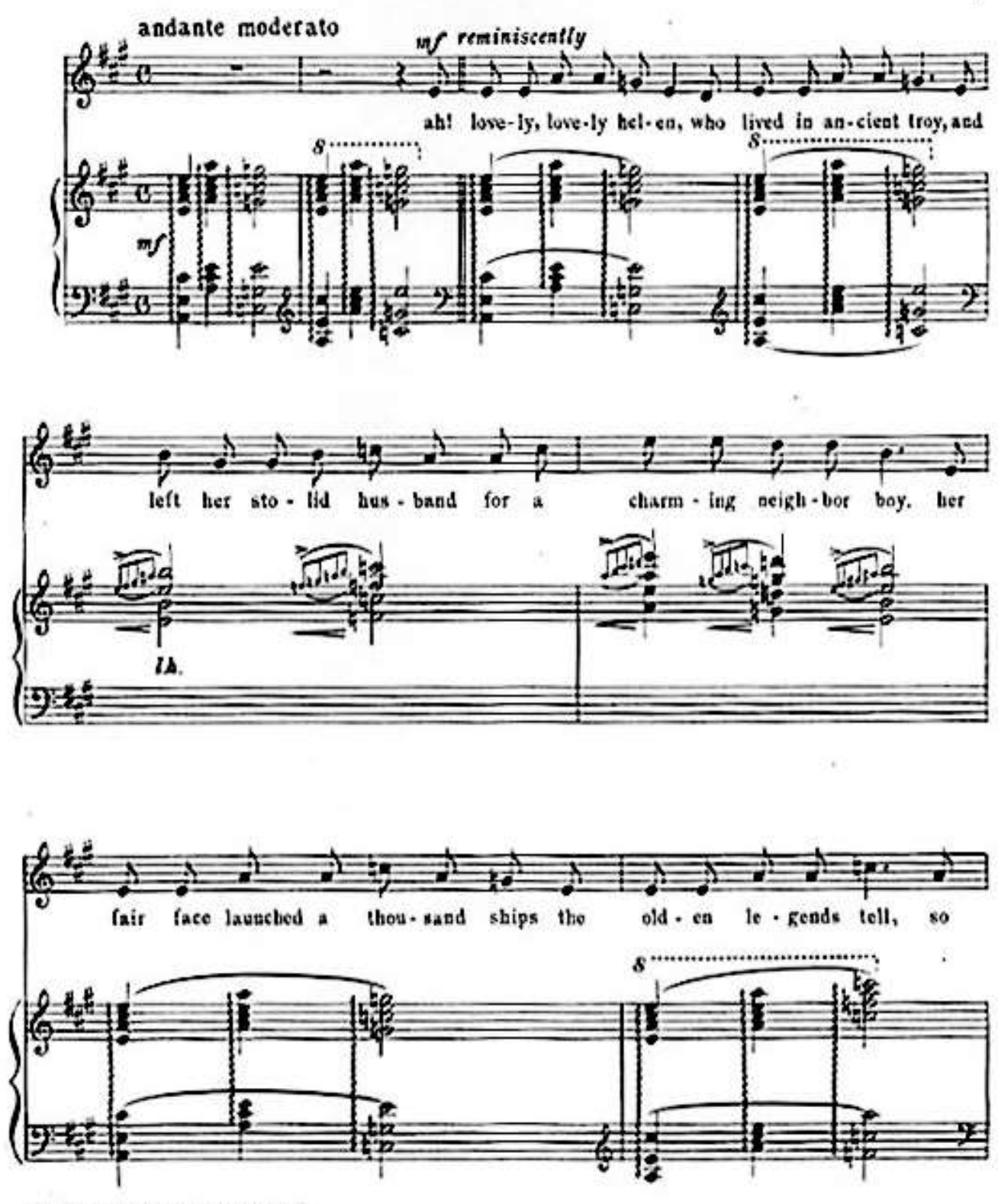

tros" hove igzles of toreiy ladies"

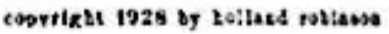



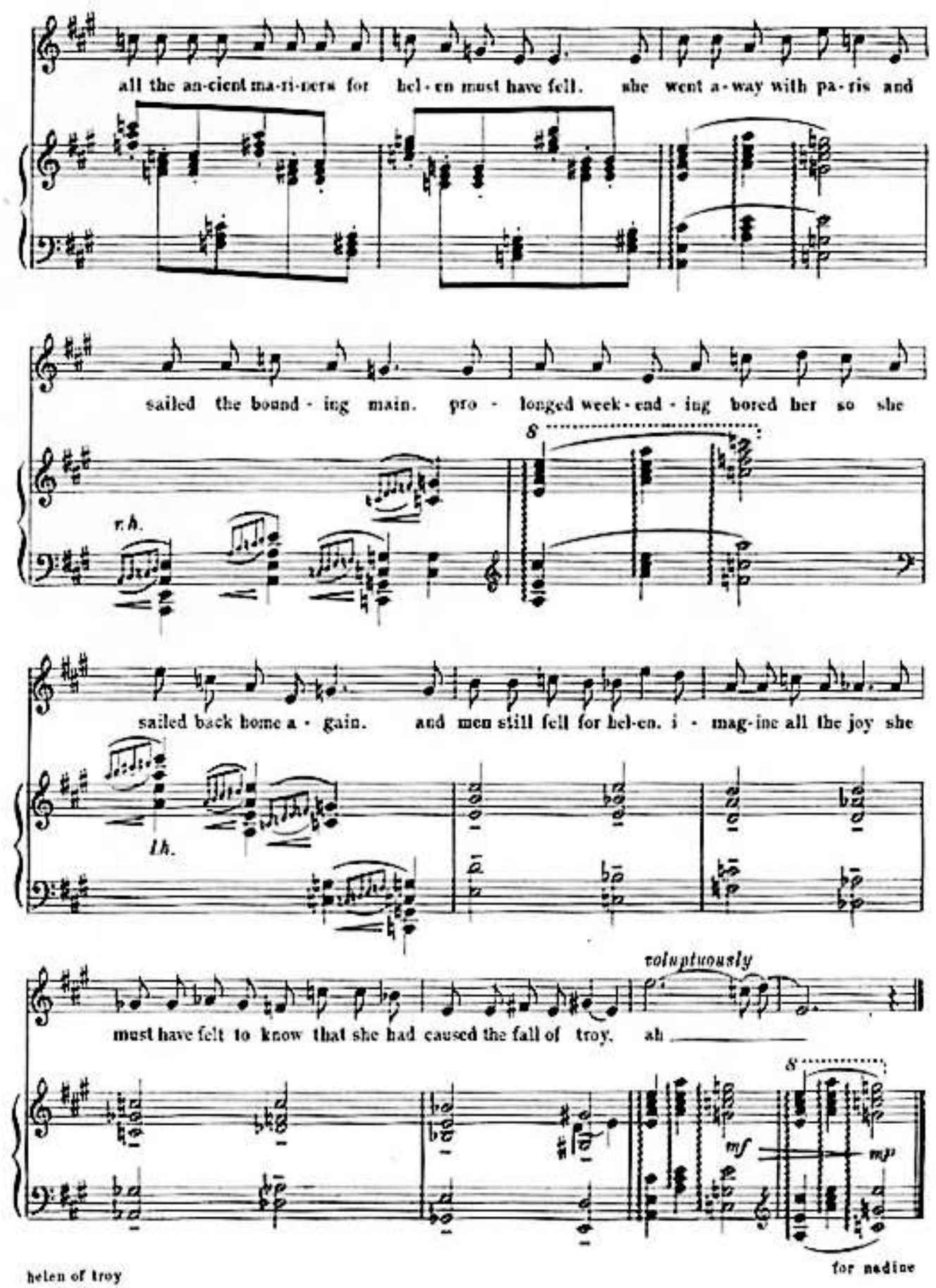

The songs are light, and tonal in scope, and usually have an accompanying figure or two, often established in the introduction. Yet there is spice: "lucrezia borgia" begins with a major seventh/minor seventh alternation, for example. Colorful use of other seventh and ninth chords, used in jazz and the Parisian nightclubs of the 1920s and 1930s as well as in more classical works, and liberal use of the tritone in the melody, add to the overall effect (Figure 7). 
Figure 7. Drawing by Mac Harshberger, and major seventh and ninth chords, first page of "lucrezia borgia"

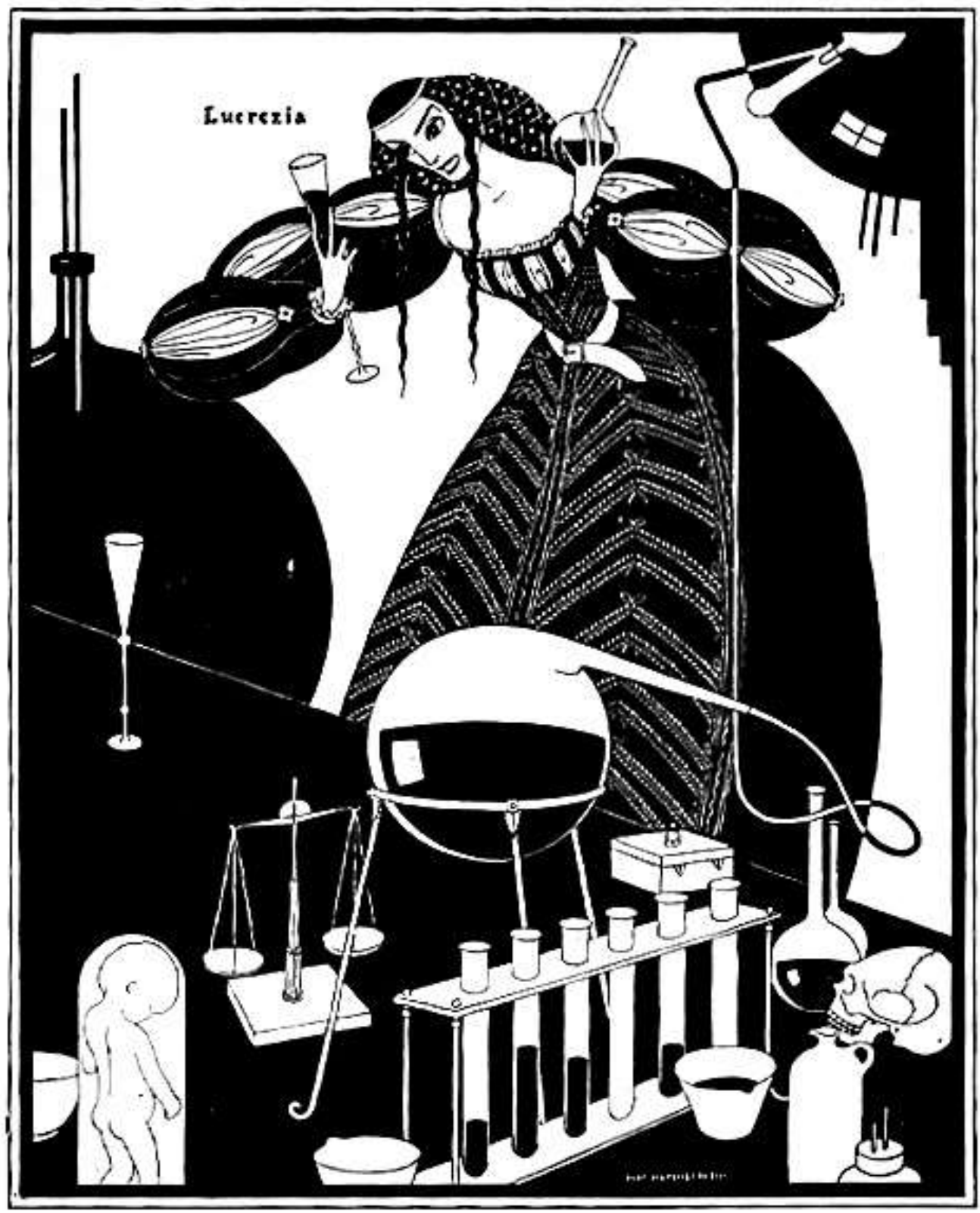




\section{lucrezia borgia}

Iyric and music by

bolland robinson
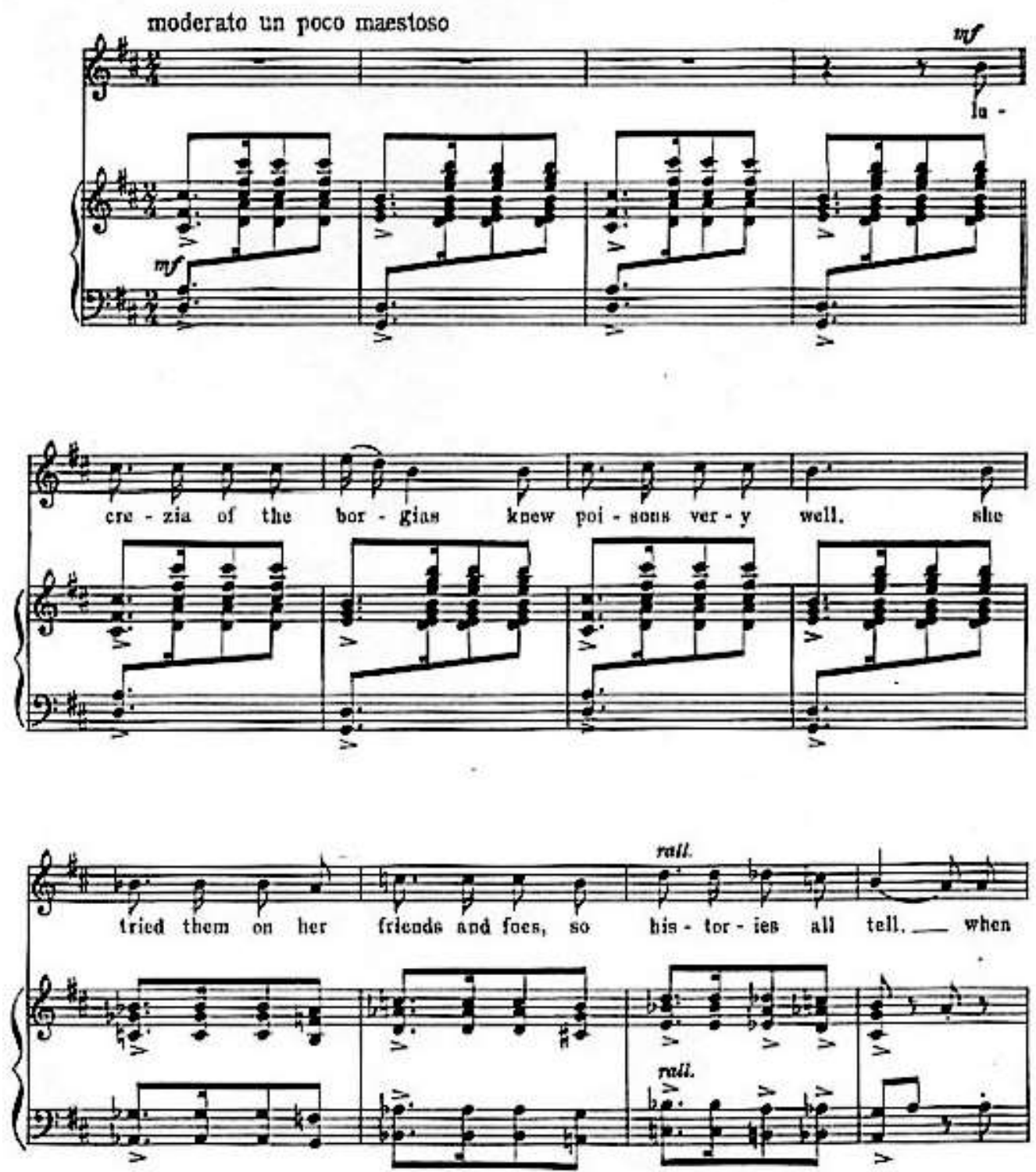

Crom "lase byrtes of Jowely intien".

\section{A Noted Performer}

The songs were premiered by Radiana Pazmor, noted contralto, who was a champion of American art song during her long and distinguished career. She was a friend of Harshberger and Robinson, and especially gave performances of 
Ives as well as other American composers in the 1920s and 1930s. ${ }^{7}$ Pazmor was also the subject of a Harshberger drawing used in the front of Loose Lyrics of Lovely Ladies (Figure 8).

Figure 8. Mac Harshberger drawing of Radiana Pazmor, contralto, with information on the premiere of Loose Lyrics

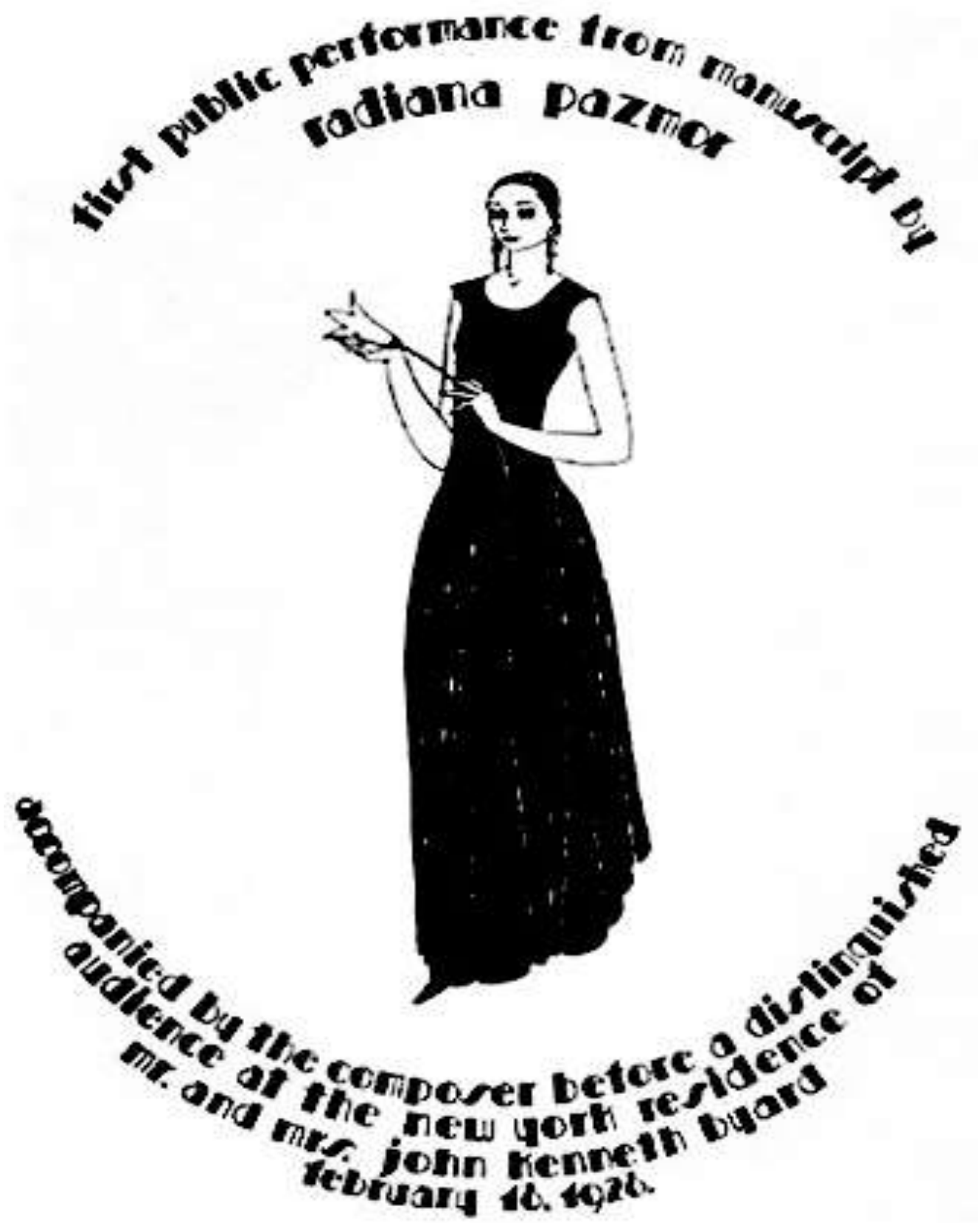

7. Lindley, Singer Radiana Pazmor and American Music: The Performer as Advocate, 128. 


\section{Harshberger's Drawings}

Each song in Loose Lyrics of Lovely Ladies is preceded by a Mac Harshberger drawing/caricature of the personage, in India ink, that follows (Figure 7). Whether these drawings were present at the original premiere for the audience to view is uncertain. The drawings are clearly art deco in style. Harshberger studied under Max Denis (1870-1943), a noted illustrator, teacher and decorative artist, and was also susceptible to other art deco influences in both France and the United States. Of course, the International Exhibition of Modern Decorative and Industrial Arts (Exposition internationale des arts décoratifs et industriels modernes), an exhibition that featured the Art Deco style, occurred in 1925, when Harshberger and Robinson were in Paris. Max Denis was, along with Edouard Vuillard, a member of the Nabis (definition: prophet). While the Impressionists believed in light and color, the Nabis, according to Denis, believed that the artist's purpose "lies in creating a world unto itself, apart from nature, and that form and color were expressive in and of themselves." Harshberger later derived his income from his unique designs, including advertising, magazine illustrations, and murals, including a giant mural for the South Carolina Building at the 1939 New York World's Fair. He was later employed as a professor at the Pratt Institute in New York from 1940-1955. ${ }^{8}$

The "elegance of line" that Whitney refers to is seen in his drawings of the ladies in Loose Lyrics, whether that line be curved or straight. In examining the drawing of "Helen," one is first drawn to the center and the subject's face, actually a bit off-center. Then one's eyes are almost immediately drawn to that bit of detail, a stereotypical Grecian urn. The other portions of the drawing are almost equally divided between straight and near-straight, curved, and wavy lines, comprising Trojans, shields, Helen's blouse and skirt, the mythical horse, Paris playing a lyre, and backgrounds. The lettering is done in a stylized Greek alphabet; the balance of black and white is symbolic, perhaps, of the balance or the rocking of the boat (Figure 9). The overall effect is one of the femme fatale, as seen in the earlier drawings of Max Denis, Aubrey Beardsley, and others.

8. William Whitney, An Elegance of Line: The Graphic Art of Mac Harshberger (San Francisco: J.L. Publications, 1996), 5-7. 
Figure 9. Mac Harshberger drawing of "helen" (Helen of Troy), from Loose Lyrics

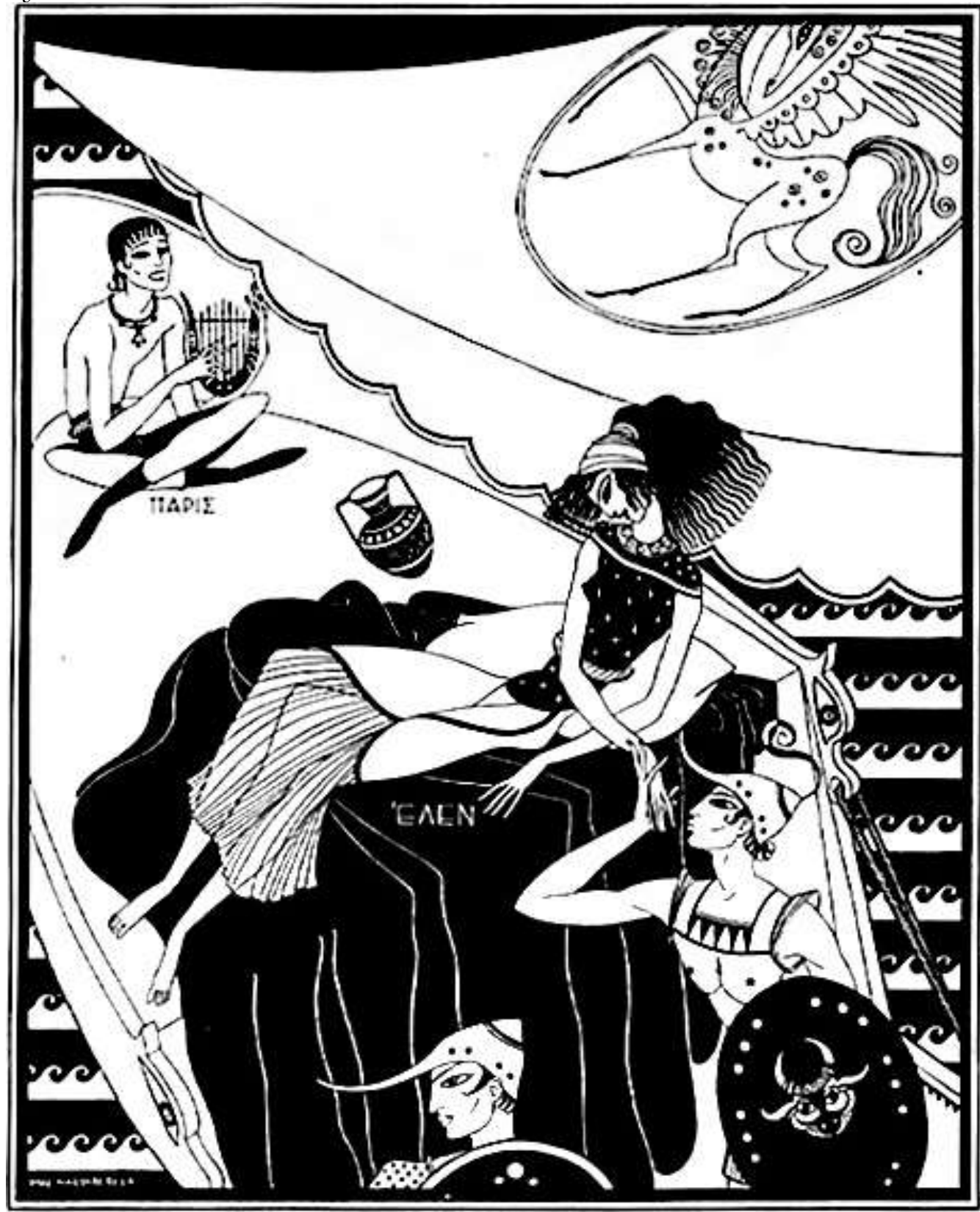

\section{Robinson's Possible Compositional Influences}

One can only make conjectures about musical influences on the composer at this time, if he was sensitive to the musical world in Paris. Robinson lived by playing piano in motion picture establishments and for vaudeville dancers, and, when he found out that Harshberger was going to Paris, accompanied him 
and studied composition, though formal study is not indicated. ${ }^{9}$ One assumes by the publication dates of Carcassonne and Company, and of other songs, that Robinson and Harshberger did indeed return to the United States in 1924 or 1925, as documented by Whitney. ${ }^{10}$ The musical influences immediately prior to this, particularly those of song, could have included the Jean Cocteau songs of Arthur Honegger (Six Poesies de Jean Cocteau, 1920-1923); the previously mentioned "La Diva de 'l'Empire"' (1919) by Satie, as well as popular songs of French music halls. The light flavor of the songs is also evocative of the music of other members of Les Six, especially Francis Poulenc (i.e., "Violon" or "Hôtel"). However, Carcassonne and Company has no reference to music heard or studied by Robinson while in France. Yet these French songs contain several similarities to the Loose Lyrics of Lovely Ladies in their lightness, use of melodic and harmonic style, accompaniment figures, and their texts. The songs of Cole Porter are also brought to mind in terms of their witty texts and cabaret flavor, although they date from a somewhat later time period, and are primarily for the theatre. At any rate, Loose Lyrics would make a fine closing set of songs on a recital, especially if performed with projections of the illustrations.

Robinson suffered from depression and alcoholism, and eventually succumbed to the latter disease. ${ }^{11}$ One wonders what other songs and drawings might have come forth had Robinson lived past his approximate death date of 1945. Harshberger suffered a stroke in 1960, but recovered enough to continue his work and teaching, eventually succumbing to another stroke in 1975.

\section{Conclusion}

If an American art deco style in art and music could be defined on the basis of Robinson and Harshberger's Loose Lyrics of Lovely Ladies, it would be light, airy, and clever, full of witticism and double entendre, and illustrated with elegance, as one might expect. Some might say that the songs of Loose Lyrics are substandard stylistically and are insignificant in the realm of art song literature. This might be true, but the author maintains that they are more undiscovered than substandard. Art song literature had an expanded canon at this time, especially with the lighter fare of cabaret songs, and the music of Poulenc and Satie, as previously discussed. The songs of Robinson and Harshberger represent a unique glimpse into the illustrated songbook of the art deco late 1920s and early 1930s, and are not unlike their more famous counterparts.

9. Ibid., 9-10.

10. William Whitney, "Art Deco and 1920s Paris: Preserved for Posterity," Nob Hill Gazette (San Francisco, February 1998b), 22.

11. William Whitney, Personal correspondence with the author, 2001. 
Appendix 1

\section{Holland Robinson}

\section{List of Songs} printed.

"Nipponese." Poem by Katharine Harshberger. (n.d.) 200 originally

"Chimera." Poem by Georgie Carneal in the Smart Set magazine. (n.d.) 200 originally printed.

"Silence." Poem by Margaret Widdemer. Dedicated to Madame Marguerite d' Alvarez. (n.d.) 200 originally printed.

"Thou." Poem by Mavorette Moore. Dedicated to Harrison and Myrtle. (n.d.) 200 originally printed.

"A Javanese Lullaby." Poem by Ian Wolfe. 1921. Robinson \& Wolfe.

Nursery Rhymes for the petits francais. Paris. Holland Robinson. 1925.

Zoological Soliloquies. Drawings by Mac Harshberger. Kay Harshberger, lyricist. New York: A. and C. Boni, 1926.

Mother Goose Song Book. Drawings by Mac Harshberger. Lyrics by Holland Robinson. New York: A. and C. Boni, 1926.

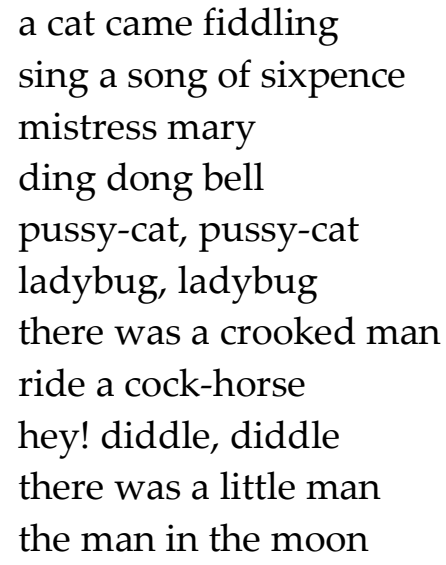

Travelogue Tales. Lyrics by Kay Harshberger, drawings by Mac Harshberger. New York: Holland Robinson, 1927.

"Circus Day." Lyrics by Kay Harshberger, drawings by Mac Harshberger. New York: Holland Robinson, 1927.

Ballads of a New York Child. Poems by Holland Robinson. Drawings by Holland Robinson. Dedicated to Mac \& Kay Harshberger. 1928. Holland Robinson. 500 originally printed.

the museum of natural history the rockefeller carillon 
the aquarium

the ferry boat

greenwich village

Brooklyn bridge

the riverside bus

the woolworth building

the opera

the subway

Broadway

Harlem

Robinson, Holland, and Mac Harshberger. 1928. Loose Lyrics for Lovely Ladies. New York: Holland Robinson. 150 originally printed.

marie antoinette
madame sand
mona lisa
josephine
pocahontas
helen
elizabeth
lucrezia borgia
margaret
louise la vallière
cleopatra
maria theresa

"My Gangster." Poem by Holland Robinson. Dedicated to Radiana Pazmor. 1931.

"Modern Mama." Poem by Holland Robinson. Dedicated to Anne Sutherland. 1932. Horace Terrell, New York.

"That Minor Waltz." Poem by Holland Robinson. Dedicated to Elizabeth Kay and Isabel. 1932. Horace Terrell, New York.

"I Never, Never Knew." Poem by Holland Robinson. Dedicated to Fred Heidenson. 1932. Horace Terrell, New York. 
Appendix 2

\section{Texts of Loose Lyrics of Lovely Ladies}

\section{marie antoinette}

marie antoinette was a queen worth while.

most costly her wardrobe, more costly her smile, ah!

cardinals, courtiers, pages, kings sued for her favors and other things, ah!

the french revolution, one ill-starred day,

swept our marie antoinette away.

she calmly went to the block, they said.

well, it wasn't the first time she'd lost her head, ah!

\section{madame sand}

madame sand was noted for her loves more than her looks.

she loved a lot of gentlemen, and wrote a lot of books.

she traveled here, and traveled there, saw lands both near and far,

and always with her luggage were a lover and cigar.

she fell in love with chopin, with de musset, some said liszt.

in fact the nineteenth centure saw very few she missed.

though pious dames condemned her for her democratic stand, they almost died of envy, when they thought of madame sand.

\section{mona lisa}

leonardo's mona lisa may not have been fast, but when one sees her portrait, why one knows she had a past. some call her smile inscrutable, to me 'tis plain as day: with just one quart of rare old wine most girls will smile that way. ah! lisa was a charming girl, 'tis certainly a cinch she was popular with other gents beside the great da vinci.

now in the louvre she smiles and smiles while tourists hold their breath. some day she'll surely lose her poise, and laugh herself to death.

\section{josephine}

josephine was more than queen, more than queen indeed. as widow, mistress, empress, and as divorcee, we read of all her many exploits, when as bonaparte' s preferred, she turned gay paris upside down with just a single word. her end was somewhat tragic and much did she endure. the poor thing spent her later years 'mid empire furniture. no doubt she oftimes thought of all the things that might have been, but she knew how to console herself, for she had been more than queen. yes, far, far more than queen. 


\section{pocahontas}

princess pocahontas was a maid whom nothing daunted.

she knew exactly what she wished and had just what she wanted.

and when she saw her father had designs on john smith's head,

she saved the "paleface" captain and the two of then were wed.

alas! in that departed day not one benighted soul

had ever heard of sanger, or her gospel: birth control.

had pocahontas and her john been told the truth, not myths,

our telephone directories would not be crammed with smiths.

\section{helen}

ah! lovely, lovely helen, who lived in ancient troy,

and left her stolid husband for a charming neighbor boy.

her fair face launched a thousand ships the olden legends tell,

so all the ancient mariners for helen must have fell.

she went away with paris and sailed the bounding main.

prolonged weekending bored her so she sailed back home again.

and men still fell for helen. imagine all the joy

she must have felt to know that she had caused the fall of troy.

\section{elizabeth}

elizabeth of england was a lady great and bold.

the things they tell about her makes your blood run hot, then cold.

hey, nonny, nonny, nonny.

she ruled her land with iron hand and lords of high degree

all did their best to interest this dame of majesty.

hey, nonny, nonny, nonny.

alas! she would have none of them and said, "i'll rule alone.

i do not want a consort, 'twould just clutter up my throne."

somebody dubbed her, "virgin queen," and one could hardly blame

will shakespeare when he softly murmured, "what's in a name?"

hey, naughty, naughty, naughty.

\section{lucrezia borgia}

lucrezia of the borgias knew poisons very well.

she tried them on her friends and foes, so histories all tell.

when anyone annoyed her she would give a little ball

and though a lot of people came, why none went home at all.

ah! life today has lost all charm, 'tis not at all complex.

a chemist is not needed for those persons who might vex

lucrezia, were she here today, would save her soul from sin,

by simply shifting all the blame on purest bootleg gin. 


\section{margaret}

queen margaret of navarre was not a royal "blue stocking."

the things that she did and said were sometimes rather shocking.

the gayeties at marge's court, when guests come there to tarry, could hardly be imagined at the court of george and mary. among her choice possessions was no remington to hammer on, which probably is why is once finds such charm in her "heptameron." if she could be alive today, to add to all her glories, 'tis likely she could be induced to edit "snappy stories."

\section{louise la vallière}

louise la vallière was of beauté trés fine.

her wit was most brilliant her repartee keen ah!

king louis the fourteenth found her to his taste.

he gave her huge diamonds, (today they give paste.) ah!

when king louis tired of his lovely louise,

she found herself bored by all other men's pleas.

"as louis has left me," she said with a nod,

"i'll enter a convent and hobnob with god."

\section{cleopatra}

now cleopatra, egypt's queen, lived long ago. they say

that many things that cleo did could not be called "au fait."

a catalog of all her loves i'll not attempt to make.

she poisoned those who bored her, or exposed them to a snake

at last she met mark antony, but he was called away

before she chanced to tire of him. ('twas luck for him, i'll say).

cleo killed herself for love, (it quite annoyed her mother),

and nevermore was heard to say, come slaves, asp me another.

\section{maria theresa}

maria theresa was pious and good.

she did ev'ry thing that a pious queen should.

her virtue was famous, her pride was the same.

no scandalous gossip could sully her name.

she prayed ev'ry morning, she prayed ev'ry noon.

she never made love by the light of the moon.

to think of a lover would give her a chill.

she never was happy. the moral? what you will 


\section{Bibliography}

Robinson, Holland, and Harshberger, Mac. Loose Lyrics of Lovely Ladies. New York: Holland Robinson, 1928.

Whitney, William. "Art among Friends." The Sophisticate: Journal of the Art Deco Society of California. San Francisco: Autumn (1998a), 1-7.

Robinson, Holland. Carcassonne and Company: The Diary of an Art Student. Binghamton, N.Y.: Vail Ballou Press, 1926.

Lindley, Nancy E. Singer Radiana Pazmor and American Music: The Performer as Advocate. Unpublished doctoral dissertation, University of Maryland, 1993.

Satie, Erik, and Martin, Charles. Sports et divertissements: Twenty Short Pieces for Piano. Paris: Lucien Vogel, 1914.

Whitney, William. An Elegance of Line: The Graphic Art of Mac Harshberger. San Francisco: J.L. Publications, 1996.

Whitney, William. "Art Deco and 1920s Paris: Preserved for Posterity." Nob Hill Gazette. San Francisco, February 1998b. 